\title{
Design of A Simple Pyrolysis Reactor for Plastic Waste Conversion into Liquid Fuel Using Biomass as Heating Source
}

\author{
Aditya Kurniawan * , Bambang Sugiarto, and Andri Perdana \\ Department of Chemical Engineering, Faculty of Industrial Engineering, UPN"Veteran” Yogyakarta
}

Jln. SWK 104 (Lingkar Utara), Condongcatur, Yogyakarta, 55283

\section{Artikel histori :}

Diterima 02 October 2020 Diterima dalam revisi Diterima 17 January 2020 Online 31 March 2020

\begin{abstract}
A design that emphasizes simplicity and cost-effectiveness is applied to the plastic pyrolysis reaction system to produce liquid fuel. The reactor is fabricated from the waste refrigerant tank. The energy source for pyrolysis is generated by the combustion of biomass pellets. Forced convection by an electric blower is utilized to enhance the combustion efficiency and thus increase the heating rate with the overall average temperature at $412{ }^{\circ} \mathrm{C}$. The coiled pipe is employed as a condenser system with water as its cooling media. The quantity of liquid product is measured for a different mass of PET-type plastic waste feed, with a maximum value of $17.7 \% \mathrm{w} / \mathrm{w}$ of feed mass is obtained. The physical characteristic of the liquid product is then analyzed using standard methods. It is found that its characteristics have approached the specification of commercial liquid fuel in the domestic market, with a liquid specific gravity of 0.776 and a heating value of $46 \mathrm{MJ} / \mathrm{kg}$.
\end{abstract}

Keywords: plastic pyrolysis; liquid fuel; biomass combustion; reactor design

\section{Introduction}

The world population continues to increase, especially for Indonesia as one of the largest countries in terms of its population. The population in Indonesia is projected to reach some 311.6 million in 2045 (Bappenas \& BPS, 2018). This will become a demographical bonus on one side, however, it also will create an unwanted excess, such as the problem of communal waste. The type of waste could be in the form of organic waste, such as food spoils, leaves, and other organic material, or inorganics such as paper, plastic, and hazardous waste. Plastic is one type of waste that takes a long time to decompose, even thousands of years. Several practices have been proposed to overcome this problem. The simpler one is by applying the 3R principle: to reduce, reuse, and recycle the waste. However, for non-recyclable plastic-based material, another type of technology is utilized, such as by pyrolysis to convert it into liquid fuel.

Pyrolysis is a process of complex material decomposition into smaller ones, by using an intensive heating treatment in the oxygen-poor atmosphere. For plastic pyrolysis, the main product is oil, gas, and char. (Sharuddin et al., 2018). Several aspects that influence the performance of plastic pyrolysis are temperature, reactor type, pressure, residence time, and type and flow rate of gas for fluidized bed reactor type. Temperature is the most important factor because pyrolysis is a process of breaking/cracking the chemical-bond inside the molecule. The temperature in the molecular scale related to the vibrational energy magnitude of the molecule. Therefore, a high temperature promotes the chemical bond breaking. The optimum temperature for pyrolysis is different for each type of plastic. For PET, the optimum temperature is $350-520{ }^{\circ} \mathrm{C}$, and for LDPE at the range of 360-550 ${ }^{\circ} \mathrm{C}$. The quite similar range also applies for HDPE, at 378-539 ${ }^{\circ} \mathrm{C}$ (Anuar Sharuddin et al., 2016). Besides temperature, the heating rate also brings a significant effect, either for conversion rate or product composition and calorific value (Tao et al., 2013).

In general, there are three components of the pyrolysis reactor: the heater, reactor, and cooler. For the heater, gas (LPG) combustion is generally used (Gaurh \& Pramanik, 2018) as the heat source. Another type of fuel is heating oil (Lee, Yoshida, \& Yoshikawa, 2015). In a laboratoryscale experiment, electricity is preferable due to its simplicity and controllability (Abdullah et al., 2018; Yuliansyah et al., 2015).

Despite its abundance in our country, the biomass fuel is still rarely used as the pyrolysis heating source and few have studied it. Presumably, the low efficiency of biomass stove becomes the factor. A simple biomass stove with natural convection air supply can only generate $8-12 \%$ of the heating efficiency. The combustion efficiency can be improved by applying forced convection to increase air to fuel ratio and therefore make the combustion more efficient.

The reactor type applied for pyrolysis reaction includes batch, semi-batch, fixed bed, fluidized bed, or the modification of these types. The batch reactor is simpler 
for its fabrication and operation; therefore it is more suitable for laboratory/small scale process. This reactor type has been used for plastic waste pyrolysis in a pilotscale (Aziz et al., 2017).

The cooler is used to condense the vapor produced by the reactor. However, the operating condition of the condenser also affects the liquid fuel yield and characteristics. Therefore, it must be properly designed. Thahir et al.,(2019) applied a bubble cup distillation column integrated with the pyrolysis reactor to maximize liquid fuel products. The reactor-distillation system is run in a vacuum condition to reduce the vaporization temperature and maximize liquid yield. However, installing a vacuum system will give additional technical complexity and also cost.

The research aims for a simple bench-scale pyrolysis reactor design dedicated mainly to community-level waste management. Therefore, the simplicity of design and the cost of fabrication becomes the most considered factor instead of the reactor performance. The apparatus consists of a heating system, reactor, and cooler. The source of heating is a biomass stove using a biomass pellet as its combustible material. Forced convection is provided by using an electrical blower to boost the combustion efficiency of the biomass stove. The reactor is mainly fabricated from a waste refrigerant tank as its main constituent; therefore it gives added value into waste material. The condenser system uses a cooling coil with the water as cooling media. This pyrolysis equipment is the test to thermally convert the PET-type plastic waste into liquid fuel. This design is expected to maximize the utility of reusable material to give an added value to a waste (plastic waste) by converting it into a more valuable material.

\section{Materials \& Methods}

\subsection{Materials \& Equipment}

The schematic design of the pyrolysis reactor is shown in Figure 1. The apparatus is fabricated from a usedrefrigerant steel tank (Klea ${ }^{\mathrm{TM}}$ refrigerant,) with wall thickness about $2 \mathrm{~mm}$ that is formed and welded into a pyrolysis chamber. The bottom part of the apparatus is utilized as a plastic waste reactor with a maximum capacity of $3 \mathrm{~kg}$ of plastic waste per run. The feeder lid is placed at the side of the cylinder. The reactor dimension is $35 \mathrm{~cm}$ wide and about $75 \mathrm{~cm}$ of column height (Table 1). Temperature measurement is facilitated by a thermocouple probe (Digital Instrument TM-902C K type) installed at the bottom, middle, and upper part of the reactor.

Table 1. Pyrolysis reactor geometry

\begin{tabular}{lc}
\hline Geometry & Size \\
\hline Feed chamber length & $45 \mathrm{~cm}$ \\
Cylinder diameter & $35 \mathrm{~cm}$ \\
Cylinder height & $75 \mathrm{~cm}$ \\
\hline
\end{tabular}

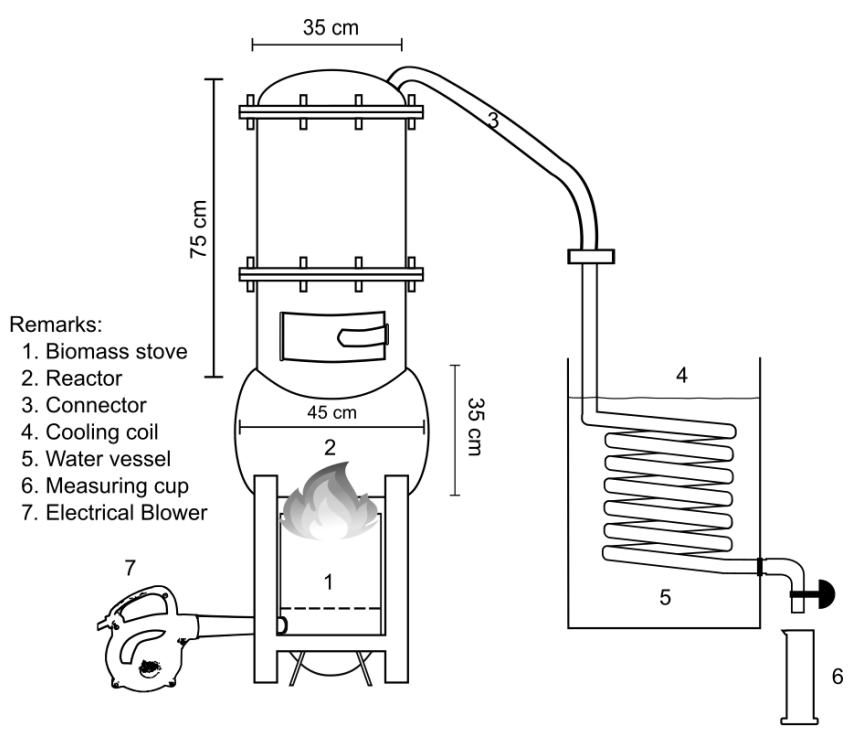

(a)

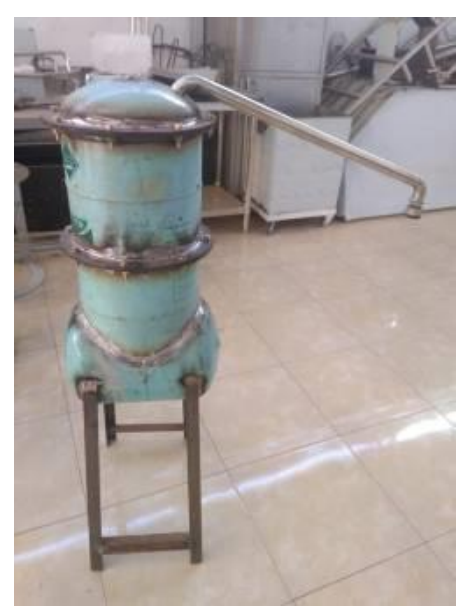

(b)

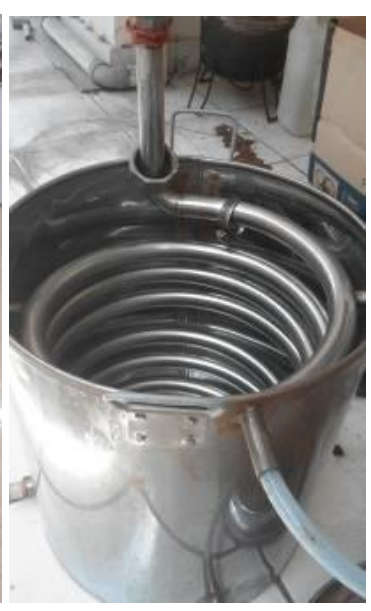

(c)
Figure 1 (a) Pyrolysis reactor schematic design (b) pyrolysis reactor picture (c) cooling coil

Plastic waste of PET-type is used as the feed. It is collected as used water bottle from several garbage banks in Yogyakarta. Biomass pellet as the combustion fuel is gathered from KUD Mungkid Utara, Magelang. Finally, the water used as cooling media is taken from the water distribution system in the PPTK I laboratory, administered by the Chemical Engineering Department, UPN "Veteran" Yogyakarta.

\subsection{Experimental procedures}

The PET plastic waste was pretreated by cleaning it from dirt and cutting it into $1-2 \mathrm{~cm}$ in diameter. Then it was dried under the sunlight and got weighed. The plastic was fed into the reactor for several mass variations $(500-2000$ gr). The biomass pellet was loaded into the combustor and then compacted to maximize the capacity. It was periodically added during the combustion to maintain the heat rate. It consumed about $3.5-4.5 \mathrm{~kg}$ of pellet for each run. Forced convection supplied by an electric blower 
action is applied to improve combustion efficiency. The process was carried out until there was no detected drop of liquid product. The vapor product of pyrolysis was condensed by the condenser coil. Afterward, the liquid product was collected in the measuring tube to determine the volume. The liquid fuel characteristics to be measured include specific gravity 60/60 (ASTM D-1289), viscosity (ASTM D-445), distillation properties or IBP/FBP (ASTM D-189), and flash point (ASTM D-93). The heating value was obtained by empirical correlation based on liquid fuel specific gravity (Demirbas \& Al-Ghamdi, 2015).

\section{Results \& Discussions}

\subsection{Combustion Temperature \& Heating Rate}

The first aspect that will be discussed is the combustion system. The temperature is quite difficult to control because there are many factors affect the combustion efficiency of the biomass stove. The range of temperature measured during operation can be as low as $195{ }^{\circ} \mathrm{C}$ (because of blower operation get interrupted by power shortage) to the maximum temperature at $650{ }^{\circ} \mathrm{C}$. The average heating temperature for each feed mass is presented in Table 2, with an overall average temperature at $412{ }^{\circ} \mathrm{C}$.

Table 2. Average heating temperature applied for different feed mass

\begin{tabular}{cc}
\hline $\begin{array}{c}\text { Mass of Plastic } \\
(\mathrm{gr})\end{array}$ & $\begin{array}{c}\text { Heating Temperature } \\
\left({ }^{\circ} \mathrm{C}\right)\end{array}$ \\
\hline 500 & 372.0 \\
1000 & 413.9 \\
1500 & 468.5 \\
2000 & 393.6 \\
\hline
\end{tabular}

Several factors affect the combustion efficiency, especially in biomass stove. These factors include a flow rate of air into the combustion chamber (induced by blower action in the forced convection-type stove), air-fuel ratio, air feeding distance to the combustion chamber, and air feeding conduit diameter (Djafar \& Darise, 2018; Mirmanto, Mulyanto, \& Hidayatullah, 2018).

\subsection{Heat Balance}

The schematic of heat balance for plastic pyrolysis is presented in Figure 2. The primary heat source is fuel combustion. Depend on combustion efficiency, the fuel might not be completely burned. Also, some of the heat produced by combustion cannot be transferred to the pyrolysis reactor and dissipated into the environment. Therefore, the remainder is the available heat for the pyrolysis process. Some of this heat is utilized for pyrolysis reaction, while the other is used to heat-up the reactor material and dissipated into the environment as natural convection.

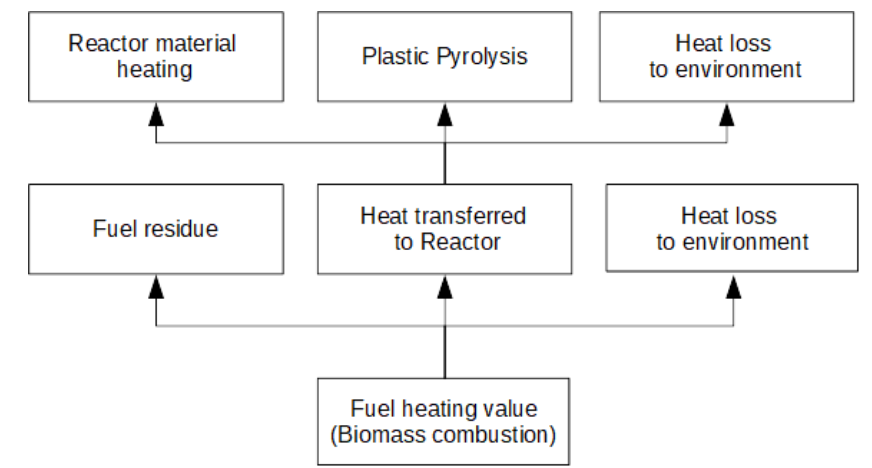

Figure 2. Schematic of heat balance

To evaluate the heat balance, those variables are calculated by the following equations

$$
\begin{aligned}
& q_{\text {combustion }}(W)=\frac{m_{\text {fuel }} * H H V}{t_{\text {pyro }}} \\
& q_{\text {pyrolysis }}(W)=\frac{m_{\text {feed }} * \Delta H_{\text {pyro }}}{t_{\text {pyro }}} \\
& q_{\text {heating }}(W)=\frac{\left(m_{f} * C_{p, f}+m_{\text {reactor }} * C_{p, s}\right)\left(T_{\text {pyro }}-T_{\text {amb }}\right)}{t_{\text {pyro }}} \\
& q_{\text {loss }}(W)=\frac{h_{c} * A *\left(T_{\text {pyro }}-T_{\text {amb }}\right)}{t_{\text {pyro }}}
\end{aligned}
$$

The value of parameters used to calculate the heat

\begin{tabular}{|c|c|c|}
\hline Parameter & Value & Ref \\
\hline Biomass HHV & $21 \mathrm{MJ} / \mathrm{kg}$ & Syamsiro, 2016 \\
\hline $\begin{array}{l}\text { Pyrolysis heat of } \\
\text { reaction }\left(\Delta H_{p y r o}\right)\end{array}$ & $214.35 \mathrm{~kJ} / \mathrm{kg}$ & Brems et al., 2011 \\
\hline $\begin{array}{l}\text { Heat capacity of tank } \\
\text { steel }\left(C_{p, s}\right)\end{array}$ & $0.5 \mathrm{~kJ} / \mathrm{kg} \mathrm{K}$ & $\begin{array}{l}\text { Perry, Green, \& } \\
\text { Maloney, } 2008\end{array}$ \\
\hline $\begin{array}{l}\text { Heat capacity of PET } \\
\left(C_{p, f}\right)\end{array}$ & $1.14 \mathrm{~kJ} / \mathrm{kg} \mathrm{K}$ & $\begin{array}{l}\text { Polymerdatabase.com, } \\
2015\end{array}$ \\
\hline $\begin{array}{l}\text { Convective heat transfer } \\
\text { coefficient }\left(h_{c}\right)\end{array}$ & $10.42 \mathrm{~W} / \mathrm{m}^{2} \mathrm{~K}$ & $\begin{array}{l}\text { Engineering Toolbox, } \\
2003\end{array}$ \\
\hline $\begin{array}{l}\text { Ambient temperature } \\
\left(T_{a m b}\right)\end{array}$ & $25^{\circ} \mathrm{C}$ & \\
\hline
\end{tabular}
balance is listed in Table 3. The formulas above are then applied to reactor operation data presented in Table 4.

Table 3. List of parameters to calculate the heat balance

By those assumptions, the average value of heat rate transferred into the reactor system for all feed weight is about $165 \mathrm{~W}$. Meanwhile, the heat rate by combustion is about $9472.2 \mathrm{~W}$. Therefore, the efficiency of heating is about $1.74 \%$. This value shows that only $1.74 \%$ of the heat produced by the combustion that is utilized by the reactor system. 
Table 4. Heat balance calculation

\begin{tabular}{cccccccc}
\hline No & $\begin{array}{c}\text { Feed mass } \\
\left(m_{f}\right), \mathrm{gr}\end{array}$ & $\begin{array}{c}\text { Pyrolysis time } \\
\left(t_{\text {pyro }}\right), \mathrm{min}\end{array}$ & $\begin{array}{c}\text { Fuel mass } \\
\left(m_{\text {fuel }}\right), \mathrm{gr}\end{array}$ & $q_{\text {combustion }}(\mathrm{W})$ & $q_{\text {pyrolysis }}(\mathrm{W})$ & $\begin{array}{c}q_{\text {heating }} \\
(\mathrm{W})\end{array}$ & $q_{\text {loss }}(\mathrm{W})$ \\
\hline 1 & 500 & 100 & 3500 & 12833.33 & 17.86 & 148.66 & 0.91 \\
2 & 1000 & 150 & 3800 & 9288.89 & 23.82 & 135.73 & 0.68 \\
3 & 1500 & 200 & 4100 & 7516.67 & 26.79 & 137.17 & 0.58 \\
4 & 2000 & 200 & 4500 & 8250.00 & 35.73 & 131.54 & 0.49 \\
\hline
\end{tabular}

Those calculations, however, do not include the latent heat contained in the pyrolysis gas before it is condensed; and the energy loss by vapour or gas leakage from the system. It is quite difficult to accurately quantify those variables because it cannot be measured precisely by the equipment that we set up. Furthermore, the temperature distribution inside the reactor is difficult to measure. The material inside the reactor might have a lower temperature than the outer reactor wall. This factor might produce errors in the calculation of the heating load. However, at least, the calculation above has given us an insight that the heat transfer efficiency of this combustion system is still low. This is due to the inefficiency of the combustion and the ineffectiveness of heat transfer from the combustion into the reactor system.

\subsection{Liquid Fuel Production}

The pyrolysis apparatus is tested for several values of plastic waste mass. The liquid fuel resulted is shown in Table 5. Figure 3 shows the appearance of the resulted liquid fuel for different reactors run. It ranges from yellow to light brown.

The volume of liquid fuel is not linearly proportional to the mass of feed put into the reactor. The data shows that the conversion decreases for the larger feed mass. The most affecting factor is the heat transfer from the heat source to all of the feed material inside the reactor. With similar heat transfer methods and temperature gradient, the heating rate will diminish for the larger mass. To increase the heat transfer rate, the heat transfer area must be set larger or the heat loss should be properly mitigated.

Table 5. By-weight conversion of PET (transparent) to liquid fuel volume

\begin{tabular}{ccc}
\hline No & $\begin{array}{c}\text { Plastic waste } \\
\text { mass (gram) }\end{array}$ & $\begin{array}{c}\text { Conversion } \\
(\% \mathrm{w} / \mathrm{w})\end{array}$ \\
\hline 1 & 500 & $17.7 \%$ \\
2 & 1000 & $13.0 \%$ \\
3 & 1500 & $12.4 \%$ \\
4 & 2000 & $10.2 \%$ \\
\cline { 2 - 2 } & Color & Yellow/Brown \\
\hline
\end{tabular}

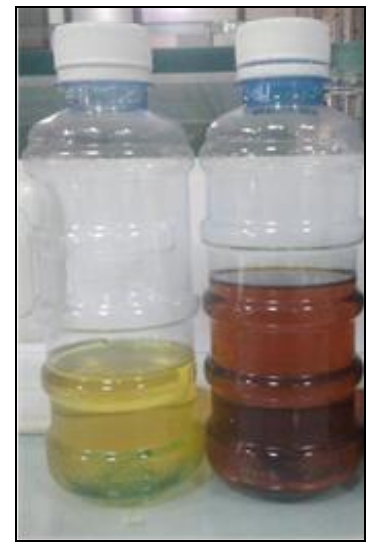

Figure 3. Appearance of the produced liquid fuel

Several types of pyrolysis reactors have been designed and patented to promote the heat transfer effectiveness, such as Auger/screw, conical spouted bed reactor, or fluidized bed reactor (Campuzano, Brown, \& Martínez, 2019; Makibar et al., 2011). This type of reactor, especially the fluidized bed, is favorable because it provides uniform mass and temperature distribution. Therefore, it improves the heat and mass transfer of the reacting component (Anuar Sharuddin et al., 2016). For conventional fixed bed reactor type, heat transfer can be optimized by installing a proper insulation system around the reactor tube to reduce the heat loss to the environment from the reactor metal cover (Armadi et al., 2017).

Previous work by other researchers succeeds to achieve a liquid yield of $46 \%$ from PET-type plastic. The applied pyrolysis temperature is in the range of $400-500{ }^{\circ} \mathrm{C}$ where the energy is generated by LPG combustion. This range of temperature is comparable with current work (Tuly, Joarder, \& Haque, 2019). Another work on the laboratory scale pyrolysis of PET obtains a liquid yield of $14.25 \%$ by setting the pyrolysis temperature at $405{ }^{\circ} \mathrm{C}$ and adding the $\mathrm{Ca}(\mathrm{OH})_{2}$ as the catalyst (Sarker et al., 2011).

\subsection{Physical Characteristics of Liquid Product}

The produced liquid fuel was analyzed to determine its characteristics. These characteristics are compared to the general specification of commercial fuel issued by Pertamina as one of the liquid fuel suppliers in Indonesia. The comparison between both types of fuel is presented in Table 6. Several key parameters, such as specific gravity, distillation temperature, and heating value; have not 
complied with the specification. However, it has approached the limiting value. This result has given a preliminary decision for further work. However, several design parameters must be properly evaluated and analyzed to improve the pyrolysis yield and liquid characteristics.

Table 6. Liquid fuel characteristic comparison between pyrolysis product and commercial fuel

\begin{tabular}{|c|c|c|c|}
\hline No. & Data & $\begin{array}{c}\text { Pyrolysis } \\
\text { Liquid Fuel }\end{array}$ & $\begin{array}{c}\text { Spec of } \\
\text { Premium*) }\end{array}$ \\
\hline 1. & Sp.Gr 60/60 & 0.776 & $0.77(\max )$ \\
\hline \multirow[t]{5}{*}{2.} & Distillation Temperature & & \\
\hline & $10 \%$ rec & 102 & $74(\max )$ \\
\hline & $50 \%$ rec & 132 & $125(\max )$ \\
\hline & $90 \%$ rec & 184 & $180(\max )$ \\
\hline & $\operatorname{FBP}\left({ }^{\circ} \mathrm{C}\right)$ & 184 & $215(\max )$ \\
\hline 3. & Residue & $7 \%$ & $2 \%(\max )$ \\
\hline 4. & Redwood Viscosity (s) & 27.3 & - \\
\hline 5. & Flashpoint $\left({ }^{\circ} \mathrm{C}\right)$ & 1 & - \\
\hline 6. & Heating Value (kJ/kg) & 46086.468 & $43969.656^{* *)}$ \\
\hline
\end{tabular}

\section{Conclusions}

A set of plastic pyrolysis apparatus, consist of the biomass combustion system, pyrolysis reactor, and cooling coil has been designed and fabricated to conduct plastic waste conversion into liquid fuel. This system maximizes the utilization of waste material. The first one is plastic waste as its feed, and the second is the reactor material that utilizes waste goods. Therefore, it will add the waste-toenergy aspect to it. The system also utilizes a renewable energy source to promote energy sustainability.

The average pyrolysis temperature is about $412^{\circ} \mathrm{C}$. By this operating condition, the apparatus can produce the liquid fuel with the maximum conversion of $17.7 \%$ on a weight basis. Based on the standard analytical procedure, its characteristics are found to have approached the specification of commercial liquid fuel in the domestic market.

Several issues related, especially, with the efficiency of combustion, heat transfer, and conversion/reaction demands an immediate analysis and evaluation of the available design to improve its performance.

\section{Acknowledgments}

The authors would like to give the highest gratitude to LPPM UPN "Veteran" Yogyakarta for its support by providing a financial resource through the scheme of internal research funding with contract No.: B/136/UN.62/PT/V/2019.

\section{References}

Abdullah, N. A., Novianti, A., Hakim, I. I., Putra, N., \& Koestoer, R. A. 2018, Influence of temperature on conversion of plastics waste (polystyrene) to liquid oil using pyrolysis process. In IOP Conference Series: Earth and Environmental Science. https://doi.org/10.1088/1755-1315/105/1/012033

Anuar Sharuddin, S. D., Abnisa, F., Wan Daud, W. M. A., \& Aroua, M. K., 2016, A review on pyrolysis of plastic wastes. Energy Conversion and Management. https://doi.org/10.1016/j.enconman.2016.02.037

Armadi, B. H., Rangkuti, C., Fauzi, M. D., \& Permatasari, R. 2017, The effect of cover use on plastic pyrolysis reactor heating process. In AIP Conference Proceedings. https://doi.org/10.1063/1.4979227

Aziz, M. A., Al-Khulaidi, R. A., Rashid, M. M., Islam, M. R., \& Rashid, M. A. N., 2017, Design and fabrication of a fixed-bed batch type pyrolysis reactor for pilot scale pyrolytic oil production in Bangladesh. In IOP Conference Series: Materials Science and Engineering. https://doi.org/10.1088/1757899X/184/1/012056

Bappenas, \& BPS. 2018, Proyeksi Penduduk Indonesia 2015-2045 Hasil SUPAS 2015 - 2045. Jakarta: Badan Pusat Statistik.

Campuzano, F., Brown, R. C., \& Martínez, J. D., 2019, Auger reactors for pyrolysis of biomass and wastes. Renewable and Sustainable Energy Reviews, 102, 372-409. https://doi.org/10.1016/J.RSER.2018.12.014

Demirbas, A., \& Al-Ghamdi, K., 2015, Relationships between specific gravities and higher heating values of petroleum components. Petroleum Science and Technology. https://doi.org/10.1080/10916466.2015.1007384

Djafar, R., \& Darise, F., 2018, Pengaruh Jumlah Aliran Udara terhadap Nyala Api Efektif dari Reaktor Gasifikasi Biomassa Tipe Fixed Bed Downdraft menggunakan Bahan Bakar Tongkol Jagung. Jurnal Technopreneur (JTech), 6(2), 94. https://doi.org/10.30869/jtech.v6i2.211

Engineering Toolbox. ,2003, Convective Heat Transfer. https://www.engineeringtoolbox.com/convectiveheat-transfer-d 430.html

Gaurh, P., \& Pramanik, H. 2018, Production and characterization of pyrolysis oil using waste polyethylene in a semi batch reactor. Indian Journal of Chemical Technology.

Irzon, R., 2012, Perbandingan Calorific Value Beragam 
Bahan Bakar Minyak yang Dipasarkan di Indonesia Menggunakan Bomb Calorimeter. Jurnal Geologi Dan Sumberdaya Mineral, 22(4), 217-223. http://jgsm.geologi.esdm.go.id/index.php/JGSM/artic le/view/121/115

Lee, S., Yoshida, K., \& Yoshikawa, K., 2015, Application of Waste Plastic Pyrolysis Oil in a Direct Injection Diesel Engine: For a Small Scale Non-Grid Electrification. Energy and Environment Research. https://doi.org/10.5539/eer.v5n1p18

Makibar, J., Fernandez-Akarregi, A. R., Alava, I., Cueva, F., Lopez, G., \& Olazar, M., 2011, Investigations on heat transfer and hydrodynamics under pyrolysis conditions of a pilot-plant draft tube conical spouted bed reactor. Chemical Engineering and Processing: Process https://doi.org/10.1016/j.cep.2011.05.013

Mirmanto, M., Mulyanto, A., \& Hidayatullah, L. R., 2018, HUBUNGAN KETINGGIAN DAN DIAMETER LUBANG UDARA TUNGKU PEMBAKARAN BIOMASSA DAN EFISIENSI TUNGKU. Jurnal Teknik Mesin. https://doi.org/10.22441/jtm.v6i4.2048

Perry, R. H., Green, D. W., \& Maloney, J. O. (2008). Perry's Chemical Engineers' Handbook, 8th Edition. McGraw-Hill. https://doi.org/10.1017/CBO9781107415324.004

Pertamina., 2016, Spesifikasi Premium. September 11, 2019 ,

https://www.pertamina.com/industrialfuel/media/207 05/premium.pdf

Polymerdatabase.com. 2015, Heat Capacity of Liquid and Solid Polymers at 298 K. January 3, 2020, http://polymerdatabase.com/polymer physics/Cp $\underline{\text { Table2.html }}$

Sarker, M., Kabir, A., Rashid, M. M., Molla, M., \& Din Mohammad, A. S. M., 2011, Waste Polyethylene Terephthalate (PETE-1) Conversion into Liquid Fuel. Journal of Fundamentals of Renewable Energy and Applications. https://doi.org/10.4303/jfrea/r101202

Sharuddin, S. D. A., Abnisa, F., Daud, W. M. A. W., \& Aroua, M. K., 2018, Pyrolysis of plastic waste for liquid fuel production as prospective energy resource. In IOP Conference Series: Materials Science and Engineering. https://doi.org/10.1088/1757899X/334/1/012001

Tao, P., Ma, X. B., Chen, D. Z., \& Wang, H., 2013, Pyrolysis of waste plastics: Effect of heating rate on product yields and oil properties. In Advanced Materials Research. https://doi.org/10.4028/www.scientific.net/AMR.666. $\underline{1}$

Tuly, S. S., Joarder, M. M. S., \& Haque, M. E., 2019, Liquid fuel production by pyrolysis of polythene and PET plastic. In $8 T H$ BSME INTERNATIONAL CONFERENCE ON THERMAL ENGINEERING. https://doi.org/10.1063/1.5115938

Yuliansyah, A. T., Prasetya, A., Muhammad, A. A. R., \& Laksono, R., 2015, Pyrolysis of plastic waste to produce pyrolytic oil as an alternative fuel. International Journal of Technology. https://doi.org/10.14716/ijtech.v6i7.1241 